\title{
Eksistensi Pondok Pesantren Salafiah Sa'adatuddaren di Era Modernisasi Pendidikan
}

\author{
Marwazi \& Abul Khoir \\ Pascasarjana UIN Sultan Thaha Saifuddin Jambi \\ E-mail: marwaziabdhamid@gmail.com
}

\begin{abstract}
In the modern era, competition in various lines of life is getting tougher, education has not escaped the demands of the modern era so that the term education modernization appears. Modernization of education wants a learning model with sophisticated technology, focusing its expertise to be able to talk a lot in the field of work. Related to this, Salafiah Islamic Boarding School which is identical with its old, old education system is considered to be no longer relevant to the development of the times demanded to be able to maintain its existence with renewal efforts which certainly does not leave its characteristics as Salafiah Islamic Boarding School. This research took place in the Salafiah Sa'a Islamic Boarding School, Seberang, Jambi City. This study aims to determine the existence of the Salafiah Islamic Boarding School in the modernization era of education, what constraints faced by the Salafiah Islamic Boarding School in the modernization era of education, and what efforts have been made by the Islamic Boarding School in the era of education. education. The method used in this research is qualitative. The types of data used are primary and secondary. The data source is the informant associated with the existence of the Salafiah Sa' adatuddaren Islamic Boarding School in the era of education modernization, which was collected through observation, interviews and documentation. The findings of this study indicate that in the current era of education modernization, the Salafiah Islamic Boarding School 'adatuddaren still exists even though the number has indeed decreased but not too significantly. The efforts made by the Salafiah Sa'a adatuddaren Islamic Boarding School to maintain its existence in the era of education modernization are good enough, only it needs to be continuously evaluated by looking at existing obstacles, and the demands and demands of the times both in the world of education and employment.
\end{abstract}

Keywords: Salafiah Islamic Boarding School; Education Modernization.

\begin{abstract}
Abstrak: Pada era modern saat ini persaingan di berbagai lini kehidupan semakin ketat, pendidikan tidak luput dari tuntutan era modern sehingga muncul istilah modernisasi pendidikan. Modernisasi pendidikan menginginkan model pembelajaran dengan tekhnologi canggih, memfokuskan diri keahlian agar mampu berbicara banyak di lapangan pekerjaan. Terkait hal ini, Pondok pesantren salafiah yang identik dengan sistem pendidikannya yang jadul, usang dianggap tidak lagi relevan dengan perkembangan zaman dituntut untuk mampu menjaga eksistensinya dengan upaya pembaharuan yang tentunya tidak meninggalkan ciri khasnya sebagai pondok pesantren salafiah. Penelitian ini mengambil lokasi di Pondok Pesantren Salafiah Sa'adatuddaren Seberang Kota Jambi. Penelitian ini bertujuan untuk mengetahui eksistensi Pondok Pesantren Salafiah Sa'adatuddaren di era modernisasi pendidikan, kendala apa saja yang dihadapi oleh Pondok Pesantren Salafiah Sa'adatuddaren di era modernisasi pendidikan, dan upaya apa saja yang telah dilakukan Pondok Pesantren Salafiah Sa'adatuddaren di era modernisasi
\end{abstract}


pendidikan. Metode yang digunakan dalam penelitian ini adalah kualitatif. Jenis data yang digunakan adalah primer dan sekunder. Sumber datanya adalah informan yang terkait dengan eksistensi Pondok Pesantren Salafiah Sa'adatuddaren di era modernisasi pendidikan yang dikumpulkan melalui observasi, wawancara dan dokumentasi. Temuan dari penelitian ini menunjukkan bahwa di era modernisasi pendidikan saat ini Pondok Pesantren Salafiah Sa'adatuddaren masih tetap eksis walaupun dalam jumlah angka memang mengalami penurunan namun tidak terlalu signifikan. Upaya yang dilakukan oleh Pondok Pesantren Salafiah Sa'adatuddaren untuk menjaga eksistensinya di era modernisasi pendidikan sudah cukup baik, hanya saja perlu terus di evaluasi dengan melihat kendala yang ada, dan tuntutan serta pemintaan zaman baik dalam dunia pendidikan maupun lapangan pekerjaan.

Kata-kata kunci: Pondok Pesantren Salafiah, Modernisasi Pendidikan.

\section{Pendahuluan}

Pondok pesantren merupakan lembaga pendidikan Islam tertua di Indonesia yang kegiatannya berawal dari pengajian kitab. Secara implisit, pondok pesantren dikonotasikan sebagai lembaga pendidikan Islam tradisional, namun tidak berarti pondok pesantren tertutup untuk melaksanakan inovasi. Pesantren hakikatnya adalah sebuah lembaga pendidikan keagamaan yang memerankan fungsi sebagai institusi sosial, menjadi sumber nilai dan moralitas, menjadi sumber pendalaman nilai dan ajaran keagamaan, menjadi pengendali filter bagi pengembangan moralitas dan kehidupan spiritual, menjadi perantara berbagai kepentingan yang timbul dan berkembang di masyarakat dan menjadi sumber praktis dalam kehidupan. Sebagai institusi sosial maka pesantren memiliki dan menjadi pedoman etika dan moralitas masyarakat, karena pesantren adalah institusi yang melegitimasi berbagai moralitas yang seharusnya ada di dalam masyarakat. ${ }^{1}$ Tujuan pendidikan yang baik akan mendukung tujuan pendidikan nasional yang tercantum pada Undang-undang Republik Indonesia No 20 tahun 2003 tentang sistem pendidikan Nasional.

Tujuan terbentuknya pondok pesantren yaitu membimbing anak didik untuk menjadi manusia yang berkepribadian Islami, yang dengan ilmu agamanya dia sanggup menjadi seorang tokoh agama Islam di lingkungan masyarakat sekitar, dan untuk mempersiapkan para santri menjadi orang alim dengan ilmu agama yang diajarkan oleh kiyai, serta mengamalkan dan mendakwahkannya dalam masyarakat. ${ }^{2}$

Sepanjang sejarah, pesantren sebagai sebuah institusi pendidikan maupun lembaga keagamaan memang cukup menarik untuk dicermati dan diperbincangkan dari berbagai sisi. Terlebih pada saat munculnya istilahistilah era tinggal landas, modernitas, globalisasi, pasar bebas, dan lain

${ }^{1}$ Halim dkk, Manajemen Pesantren (Yogyakarta: LKiS Printing Cemerlang, 2008) hal.

${ }^{2}$ Abdul Majid dan Jusuf Mudzakkir, Ilmu Pendidikan Islam, (Jakarta: Kencana Prenada Media, 2010), hal. 235. 
sebagainya. Adapun yang menjadi fokus perbincangan atau pertanyaan dari berbagai pihak adalah bagaimana peran atau posisi pesantren sebagai sebuah institusi pendidikan di tengah-tengah arus modernisasi atau globalisasi, apakah pesantren akan tetap teguh mempertahankan posisinya sebagai lembaga tafaqquh fiddiin (yang hanya mengajarkan ilmu-ilmu agama Islam saja) secara mandiri yang bercorak tradisional atau pesantren diharuskan untuk ikut-ikutan melakukan proses pemodernisasian sistem, mulai dari perombakan kurikulum sampai pada perubahan manajemen pengelolaan.

Pada era modern ini persaingan diberbagai lini kehidupan semakin ketat, pendidikan tidak luput dari tuntutan era modern sehingga muncul istilah modernisasi pendidikan. Dalam arus modernisasi dunia pendidikan yang seperti itu, pondok pesantren tampil sebagai salah satu lembaga pendidikan Islam yang masih menunjukkan eksisitensinya di era modern ini. Memang cukup mengherankan karena pesantren identik dengan sistem pendidikannya yang jadul, usang dan sudah ketinggalan zaman tetapi yang perlu diingat bahwa pendidikan pondok pesantren sangat didukung oleh masyarakat Indonesia terutama dalam bidang kajian ilmu agama. Kesadaran yang mulai tumbuh mengenai pesantren itu sering disertai dengan apresiasi secukupnya. Misalnya dengan memberi penilaian bahwa pesantren merupakan sesuatu yang bersifat asli atau indigenous Indonesia, sehingga dengan sendirinya bernilai positif dan harus dikembangkan. ${ }^{3}$

Dalam pelaksanaannya sekarang ini dari sekian banyak sistem atau tipe pendidikan yang diselengarakan oleh pondok pesantren, secara garis besar dapat digolongkan dalam dua bentuk yang penting: 1). Pondok Pesantren Salafiyah, dan 2). Pondok Pesantren Khalafiyah. ${ }^{4}$ Namun di tengahtengah masyarakat pesantren, istilah pondok pesantren salaf lebih masyhur di banding dengan penyebutan pesantren tradisional maupun pesantren salafiyah. Pesantren salaf adalah pesantren yang tidak menyelenggarakan pendidikan formal semacam madrasah ataupun sekolah. ${ }^{5}$

Berdasarkan Grand tour di pondok pesantren Sa'addatuddaren penulis menemukan terjadinya kesenjangan antara teori dan fakta yang penulis temukan. Pertama, ditengah arus modernisasi pendidikan, Pondok Pesantren Sa'adatuddaren masih tetap bertahan dengan sistem pendidikan salafiah padahal pondok pesantren terkemuka lainnya seperti Pondok Pesantren As'ad, Pondok Pesantren Nurul Iman, Pondok Pesantren Tahfiz Qur'an Al-Mubarok dan Pondok Pesantren Al-Jauharen telah memodernisasikan pendidikannya dari salafiah ke khalafiah. Kedua, Pondok Pesantren Sa'adatuddaren masih tetap eksis dan masih tetap bisa bertahan

\footnotetext{
${ }^{3}$ Nurcholish Madjid, Bilik-Bilik Pesantren (Jakarta: Dian Rakyat, 2010), hal. 111

${ }^{4}$ Anonim, Pola Pengembangan Pondok pesantren (Jakarta: Ditpekapontren, 2008), hal. $41-42$

${ }^{5}$ Anonim, Pendidikan Islam dan Pendidikan Nasional (Paradigma Baru), (Jakarta: Ditpekapontren, 2007), hal. 79
} 
(survive) dengan identitas pendidikan salafiahnya, fakta ini penulis temukan bahwa masyarakat masih mempercayai Pondok Pesantren Sa'adatuddaren sebagai tempat menuntut ilmu anak-anak mereka dengan indikator masih tingginya jumlah penerimaan santri baru setiap tahunnya. ${ }^{6}$

Oleh sebab itu, ditemukannya permasalahan diatas maka dengan menerapkan Penelitian pendekatan kualitatif menjawab rumusan masalah sebagai berikut; (1) Bagaimana eksistensi Pondok Pesantren Salafiah Sa"adatuddaren di era modernisasi pendidikan (2) Apa kendala Pondok pesantren Salafiah Sa"adatuddaren di era modernisasi pendidikan (3) Apa upaya Pondok Pesantren Salafiah Sa"adatuddaren dalam menjaga eksistensinya di era modernisasi pendidikan, Pendekatan kualitatif adalah pendekatan yang bermaksud untuk memahami fenomena tentang apa yang dialami oleh subjek penelitian misalnya perilaku, persepsi, motivasi, tindakan dan lain-lain secara holistik, dan dengan cara deskripsi dalam bentuk katakata dan bahasa, pada suatu konteks khusus yang alamiah dan dengan memanfaatkan berbagai metode alamiah. ${ }^{7}$ Situasi sosial adalah lokasi atau tempat yang ditetapkan untuk melakukan penelitian. ${ }^{8}$ Situasi penelitian ini adalah Pondok pesantren salafiah Sa'addatuddaren yang terletak diseberang kota jambi. Sumber informasi dalam penelitian ini yaitu Wakil Mudir Pondok Pesantren Sa"adatuddaren beserta para pengasuhnya. Jenis data dalam penelitian ini yaitu data primer dan data sekunder, dimana data primer ini adalah data yang diambil langsung dari peneliti kepada sumbernya tanpa adanya perantara. ${ }^{9}$ Data sekunder adalah data yang bukan diusahakan sendiri pengumpulannya oleh peneliti. ${ }^{10}$

\section{Eksistensi Pondok Pesantren}

Secara etimologi, eksistensi atau existence berasal dari bahasa Latin existo, yang terdiri dari dua suku kata, ex dan sistere yang berarti muncul, menjadi, atau hadir. ${ }^{11}$ Sedangkan dalam kamus besar Bahasa Indonesia eksistensi diartikan dengan keberadaan, kehadiran yang mengandung unsur bertahan. Sedangkan menurut Abidin Zaenal Eksistensi adalah suatu proses yang dinamis, suatu, menjadi atau mengada. Ini sesuai dengan asal kata eksistensi itu sendiri, yakni exsistere, yang artinya keluar dari, melampaui atau mengatasi. Jadi eksistensi tidak bersifat kaku dan terhenti, melainkan lentur atau kenyal dan mengalami perkembangan atau sebaliknya kemunduran,

\footnotetext{
${ }^{6}$ Observasi di Pondok Pesantren Sa"adatuddaren, Tanggal 13-14 Desember 2017.

${ }^{7}$ Lexy J. Moleong, Metodologi Penelitian Kualitatif, (Bandung: Remaja Rosda Karya, 2010), hal. 6

8 Mukhtar, Metode Praktis Penelitian Deskriptif Kualitatif, Jakarta: Referensia/GP. Press Group, 2013), hal. 89

${ }_{9}^{9}$ Mukhtar, Bimbingan Skripsi, Tesis, dan Artikel Ilmiah, (Jakarta: Gaung Persada Press, 2007), hal. 86

${ }^{10}$ Mukhtar, Bimbingan Skripsi, Tesis ... Op Cit, hal. 90

11 Misiak, H \& Sexton, V, Psikologi Fenomenologi, Eksistensial, dan Humanistik, (Bandung: Refika Aditama, 2009), hal. 27
} 
tergantung pada kemampuan dalam mengaktualisasikan potensipotensinya. ${ }^{12}$

Kata "pondok" berasal dari bahasa Arab funduq yang berarti hotel atau asrama. Pondok berfungsi sebagai tempat tinggal bagi santri. Pondok merupakan ciri khas tradisi pesantren yang membedakan dengan sistem pendidikan tradisional di masjid-masjid yang berkembang dikebanyakan wilayah Islam negara-negara lain. Kata 'pesantren' berasal dari kata santri mendapat tambahan awalan 'pe' dan akhiran 'an' yang menunjukkan tempat. Pesantren berarti tempat para santri. Ikatan kata santri berasal dari suku kata sant (manusia baik) dan tra (suka menolong), sehingga kata pesantren dapat berarti tempat pendidikan manusia baik-baik. ${ }^{13}$ Pesantren adalah sebuah lembaga pendidikan Nasional Khas Indonesia. ${ }^{14}$ Menurut pengertian dasarnya pesantren adalah tempat belajar para santri, sedangkan pondok bearti rumah atau tempat tinggal sederhana yang dibuat dari bambu. ${ }^{15}$ Pesantren memiliki unsur sekurang-kurangnya kiai, santri, masjid sebagai tempat penyelenggaraaan pendidikan dan pondok atau asrama sebagai tempat tinggal para satri serta kitab-kitab klasik sebagai sumber atau bahan pelajaran. ${ }^{16}$

Pembangunan sebuah pesantren secara umum dilakukan secara bertahap dan melalui proses yang sederhana. Perkembangan pesantren di masa Walisongo banyak dibantu oleh pemerintah Islam Sulthan Agung, ia memberikan perhatian serius terhadap perkembangan pendidikan Islam. Kafrawi menerangkan, pada masa Sulthan Agung tersebut, pesantren telah dibagi kepada beberapa tingkatan, yaitu: ${ }^{17}$

a. Tingkat pengajian al-Quran yang terdapat di setiap desa, yang mengajarkan huruf hijaiyah, membaca al-Quran, al-Barjanzi, rukun Islam, dan rukun Iman.

b. Tingkat pengajian kitab bagi para santri yang telah khatam Alquran, tempat belajar di serambi masjid dan mereka umumnya mondok. Guru yang mengajari mereka bergelar kiyai Anom, kitab yang mula-mula dipelajari adalah kitab enam Bismillah (kitab yang berisi 6 Bismillâh arrahmân ar-rahîm). Kemudian dilanjutkan dengan Matan Takrib dan Bidâyah al-Hidâyah karangan Imam al-Ghazali. hal.16.

12 Abidin Zaenal, Analisis Eksistensial, (Jakarta: PT. Raja Grafindo Persada, 2007),

13 Jasa Ungguh Muliawan, Pendidikan Islam Integratif; Upaya Mengintegrasikan Kembali Dikotomi Ilmu dan Pendidikan Islam, (Yogyakarta: Pustaka Pelajar, 2005), hal. 156.

14 Abdul Hamid, Pemikiran Modern dalam Islam, (Bandung: Pustaka Setia, 2010), hal. 331.

15 Enung K Rukiati \& Fenti Hikmawati, Sejarah Pendidikan Islam di Indonesia, (Bandung: Pustaka Setia, 2013), hal. 103

${ }^{16}$ Samsul Nizar, Sejarah Pendidikan Islam: Menelusuri Jejak Pendidikan Era Rasulullah sampai Indonesia, (Jakarta: Kencana, 2008) hal. 286.

17 Muhmidayeli, (et.al.), Membangun Paradigma Pendidikan Islam, Pekanbaru: Program Pascasarjana UIN Suska Riau, 2007), hal. 191. 
c. Tingkat Pesantren Besar, tingkat ini didirikan di daerah kabupaten sebagai lanjutan dari pesantren desa. Kitab-kitab yang diajarkan kitabkitab besar dalam bahasa Arab, lalu diterjemahkan dalam bahasa daerah. Cabang ilmu yang diajarkan meliputi fikih, tafsir, hadis, ilmu kalam dan tasawuf.

d. Pondok Pesantren tingkat keahlian (takhassus) ilmu yang dipelajari adalah satu cabang ilmu dengan cara mendalam dan lebih spesialisasi.

Dalam penilaian umum, pondok pesantren merupakan salah satu model dari pendidikan berbasis masyarakat. Kebanyakan pesantren berdiri atas inisiatif masyarakat muslim yang tujuan utamanya adalah untuk mendidik generasi muda agar memahami dan mengamalkan ajaran-ajaran Islam dengan baik. Pesantren dengan cara hidupnya yang bersifat kolektif barangkali merupakan perwajahan atau cerminan dari semangat gotong royong yang umumnya terdapat di pedesaan. Antusiasme masyarakat terhadap pondok pesantren, menjadikan lembaga ini dapat eksis di tengah minimnya bantuan pemerintah sehingga dapat bertahan. ${ }^{18}$

Sebagai lembaga pendidikan tradisional, pondok pesantren mempunyai tiga fungsi pokok yang menjadi identitas (jati diri) pesantren, yaitu: pertama, transmisi ilmu-ilmu dan pengetahuan Islam (transmission of Islamic knowledge); kedua, pemeliharaan tradisi Islam (maintenance of Islamic tradition /indigenous); dan ketiga, reproduksi ulama (reproduction of ulama). Dalam menjalankan fungsi pertama, pesantren mempunyai andil yang besar dalam upaya transmisi ilmu-ilmu agama terutama yang berkaitan dengan AlQur"ân dan tafsirnya, Al-Hadits, kitab-kitab klasik terutama bidang teologi, fiqh dan tasawuf. Konsep tafaqquh al-fiddîn berfokus pada upaya memahami Al- Qur"ân (ayat al-qauliyah) serta kitab-kitab lain sebagaimana telah disebutkan. ${ }^{19}$

\section{Pesantren Salafiah}

"Salafiah" berasal dari kata "salaf". Salaf secara bahasa berarti sesuatu yang mendahului atau orang yang mendahului. ${ }^{20}$ salafiah merupakan penisbatan kepada golongan yang menganut faham generasi masa lalu atau pengikut generasi pertama Muslim yang shaleh (al-salaf al-shâlih) ${ }^{21}$ Secara terminologis, pondok pesantren salafiah adalah lembaga pendidikan Islam khas Indonesia (indigenous) yang diasuh oleh kyai yang memiliki kharismatik dengan menggunakan sistem asrama dengan metode pembelajarannya

18 Qomar, Mujamil, Manajemen Pendidikan Islam; Strategi Baru Pengelolaan Lembaga Pendidikan Islam, (Jakarta: Erlangga, 2010), hal. 15

${ }^{19}$ Azyumardi Azra, Jaringan Ulama Timur Tengah dan Kepulauan Nusantara Abad XVII dan XVIII, (Bandung: Mizan, 2014). hal. 99

20 Tim Prima Pena, Kamus Lengkap Bahasa Indonesia, (tk.: Gitamedia Press, tt.), hal. 566

${ }^{21}$ Arief Subhan, Lembaga Pendidikan Islam Indonesia Abad Ke-20: $\quad$ Pergumulan antara Modernisasi dan Identitas, (Jakarta: Kencana, 2012), hal. 281. 
berlangsung dalam bentuk wetonan, sorogan dan hapalan, dengan masa belajar yang disesuaikan dengan banyaknya kitab klasik yang dipelajari oleh santri yang tujuan utamanya adalah pembinaan akhlak dan misi keagamaan. ${ }^{22}$

\section{Eksistensi Pondok Pesantren Salafiah Sa'adatuddaren di Era Modernisasi Pendidikan}

Secara etimologis, modernisasi berasal dari kata modern, yang telah baku menjadi bahasa Indonesia dengan arti Pembaharuan. ${ }^{23}$ Modernisasi yang mengandung pikiran, aliran, gerakan dan usaha untuk mengubah paham, adat istiadat, institusi lama agar dapat disesuaikan dengan pendapatpendapat dan keadaan baru yang timbul oleh kemajuan ilmu pengetahuan serta teknologi modern. ${ }^{24}$ Tujuan proses modernisasi pondok pesantren adalah berusaha untuk menyempurnakan sistem pendidikan Islam yang ada di pesantren. Akhir-akhir ini pondok pesantren mempunyai kecenderungankecenderungan baru dalam rangka renovasi terhadap sistem yang selama ini dipergunakan. Perubahan-perubahan yang bisa dilihat di pesantren modern termasuk mulai akrab dengan metodologi ilmiah modern, lebih terbuka atas perkembangan di luar dirinya, diversifikasi program dan kegiatan di pesantren makin terbuka dan luas, dan sudah dapat berfungsi sebagai pusat pengembangan masyarakat. ${ }^{25}$

Pada era modern seperti saat ini, pondok pesantren salafiah dihadapkan kepada perubahan sistem sosial dan teknologi yang begitu cepat. Masyarakat sekarang ini menghendaki perubahan tata nilai kehidupan sosial dan struktur masyarakat modern dengan karakteristik sebagai antitesa dari masyarakat tradisional. Cara-cara pembelajaran klasik dianggap tidak lagi padan dengan tuntutan zaman modern sekarang sehingga mau tidak mau setiap pihak dan aspek dituntut melakukan improvisasi agar mampu bertahan dan eksis. Ditengah derasnya arus perubahan peradaban, eksistensi pesantren-pesantren salafiah mulai hilang, tidak lagi diminati karena dianggap tidak menjamin kehidupan yang mapan dalam menghadapi perubahan dan tantangan zaman. Beberapa pondok pesantren salafiah mulai berlomba mengubah jati dirinya agar tidak tenggelam karena kehilangan kepercayaan dari masyarakat, tidak mempunyai peminat atau para pelajar yang biasa disebut santri. Namun tidak begitu yang terjadi dengan Pondok Pesantren Salafiah Sa"adatuddaren, di era modernisasi pendidikan saat ini, ia masih tetap bertahan dengan jati diri salafiahnya. Berdasarkan hasil observasi penulis di lapangan, Pondok Pesantren Salafiah Sa"adatuddaren

22 Amin Haedari, dkk, Masa Depan Pesantren; dalam Tantangan Modernitas dan Tantangan Komplesitas Global, (Jakarta: IRD Press, 2008), hal. 194.

${ }^{23}$ Suwito, Sejarah Sosial Pendidikan Islam, (Jakarta: Kencana, 2008), hal. 161.

${ }^{24}$ Abudin Nata, Sejarah Pendidikan Islam pada Periode Klasik dan Modern, (Jakarta: Raja Grafindo Persada, 2010), hal. 187. hal. 155 .

${ }^{25}$ Hasbullah, Kapita Selekta Pendidikan Islam, (Jakarta: Raja Grafindo Persada, 2008), 
adalah salah satu pondok pesantren di Seberang Kota Jambi yang saat masih mampu mempertahankan ketradisionalannya di tengah-tengah arus modernisasi pendidikan. Pondok Pesantren Salafiah Sa"adatuddaren tidak banyak dipengaruhi oleh zaman sebagaimana pondok-pondok pesantren yang lain. Ada beberapa hal yang ditemui di pesantren-pesantren salafiah sebagai keunikan dan ciri khas tersendiri diantaranya adalah sistem pembelajaran. Sudah menjadi mafhum bahwa dalam dunia pesantren, sistem pembelajaran yang digunakan adalah pola klasikal. Begitu pula dengan Pondok Pesantren Salafiah Sa"adatuddaren, sebagai pondok pesantren salafiah, kurikulum pelajaran Sa"adatuddaren masih mengajarkan kitab-kitab klasik/ kitab kuning sebagai materi pelajaran pokoknya, serta pengajianpengajian yang masih saja mempertahankan sistem ngaji atau belajar secara lisan dengan penjelasan dari guru kepada seluruh murid dengan sistem dobit (mencatat dan menterjemahkan di Kitab Kuning masing-masing santri) dan hingga saat ini Pondok Pesantren Sa"adatuddaren masih menggunakan metode pembelajaran klasik seperti sorogan, wathonan, dan bandongan. ${ }^{26}$

Wawancara peneliti dengan ustadz Sulaiman Hasan selaku Wakil Mudir I Pondok Pesantren Salafiah Sa"adatuddaren menuturkan: "Sampai saat iko, Sa"adatuddaren masih macam dulu la, masih ngaji pagi dengan kitab kuning yang merupokan ciri khas pesantren salafiah, bentuk pesantren iko Insya Allah akan terus kami pertahankan dan belum ado niat untuk melakukan perubahan seperti pesantren lain." (Sampai saat ini, Pondok Pesantren Salafiah Sa"adatuddaren masih seperti yang dulu Salafiah, masih melakukan belajar Kitab Kuning sebagai ciri khas Pesantren Salafiah, bentuk pesantren ini Insya Allah akan terus dipertahankan dan belum ada niat untuk melakukan perbahan seperti pesantren lain modern). ${ }^{27}$ Pesantren bebas mengembangkan model pendidikannya tanpa harus mengikuti standarisasi dan kurikulum yang ketat. Karena cenderung pada sentralistik yang berpusat di tangan kyai. Model pendidikan seperti inilah yang berjalan di pesantren menjadi sangat beragam sesuai dengan kecenderungan dan misi yang ingin dikembangkan oleh sang kyai, yang sebagai pemimpin sekaligus sebagai pengasuh pondok pesantren.

Kitab Kuning menjadi ciri khas Pondok Pesantren Salafiah Sa"adatuddaren sehingga tergolong ke dalam kategori pesantren salafiah terletak pada kurikulum salafiahnya. Kurikulum ini dibuat oleh pengurus pondok pesantren itu sendiri berdasarkan petunjuk dan arahan dari sang Kyai. Inilah salah satu keunikan pesantren pada independensinya yang kuat, dimana ia memiliki keleluasaan dan kebebasan relatif yang tidak harus memihak atau mengikuti model baku yang ditetapkan oleh pemerintah dalam bidang pendidikan. Pondok pesantren Salafiah Sa"adatuddaren berkomitmen bahwa pelajaran kitab-kitab klasik masih sangat perlu untuk

26 Observasi peneliti, Pondok Pesantren Salafiah Sa'adatuddaren, 16 Maret Tahun 2018

27 Wakil Mudir I Pondok Pesantren Salafiah Sa'adatuddaren, ustadz Sulaiman Hasan, Wawancara peneliti, 19 Maret 2018, Tahtul Yaman Seberang Kota Jambi, Pena dan Buku Tulis, Eksistensi Pondok Pesantren Salafiah Sa'adatuddaren. 
diajarkan baik itu dalam proses pendidikan yang bersifat formal maupun non-formal. Kitab Kuning merupakan basis dan ciri khas pendidikan Islam Indonesia yakni pesantren yang perlu dipertahankan. Materi pengajaran di Pesantren Salafiah sejak dulu didominasi oleh kitab-kitab karangan ulama pengikut As-syafi"I (Syafi"iyah) dalam bidang Fiqih. Metode pembelajaran pesantren salafiah seyogyanya pada awal perkembangannya dilakukan dengan metode "ngaji duduk" dalam istilah bahasa melayu jambi, atau yang dikenal dengan bahasa wetonan yaitu merupakan istilah proses belajar mengajar dengan metode kuliah, dimana para santri mengikuti pembelajaran dengan duduk sekeliling Kyai yang menerangkan pelajaran secara kuliah dalam suatu ruangan yang cukup besar, dan para santri menyimak kitab mereka masing-masing dan membuat catatan pada pinggir kitab.

Selain itu, eksistensi suatu pondok pesantren juga dapat dilihat dari letak kepercayaan masyarakat untuk menitipkan anaknya menimba ilmu di pondok pesantren tersebut. Jumlah santri di suatu pondok pesantren menandakan bahwa pondok pesantren itu memiliki keberadaan aktual sebagai suatu wadah pendidikan dalam berpatisipasi dan memberikan kontribusi di dunia pendidikan. Eksistensi sebagai suatu unsur yang mengandung makna bertahan menunjukkan bahwa pondok pesantren dengan ditengah arus perubahan dalam suatu ciri khas tertentu dan masih memiliki peminat dan kepercayaan menandakan bahwa ia mampu bertahan dan eksis dengan apa yang ia pertahankan.

Jumlah santri yang banyak di sebuah pondok pesantren salafiah di tengah arus modernisasi pada saat sekarang ini merupakan bukti absah bahwa suatu pesantren itu ada dan eksis, aktual dalam memberikan kontribusinya. Jumlah santri merupakan bukti kepercayaan masyarakat yang sangat factual dalam eksistensi suatu wadah pendidikan. Kepercayaan untuk menitipkan anak-anak mereka belajar menimba ilmu agama pada saat sebagian masyarakat lain mengkhawatirkan akan lapangan pekerjaan setelah lulus nantinya dari pondok pesantren tersebut. Terkait dengan kepercayaan masyarakat, yang dalam hal ini adalah para orang tua dalam menitipkan anaknya untuk belajar di Pesantren Salafiah Sa"adatuddaren, dapat dilihat dari jumlah santri dari semenjak Pondok Pesantren ini berdiri hingga sekarang di era modernisasi pendidikan tidak pernah kurang dari ratusan santri. Jumlah santri yang tidak pernah kurang dari ratusan ini mengabsahi eksistensi Pondok Pesantren Salafiah Sa"adatuddaren sebagai pesantren yang memberikan kontribusi besar dalam dunia pendidikan, khususnya pendidikan agama.

Saat ini berdasarkan data yang penulis peroleh dari hasil dokumentasi, tercatat bahwa santri yang aktif belajar di Pondok Pesantren Salafiah Sa"adatuddaren adalah sebanyak 669 orang santri dari berbagai kabupaten yang ada di Provinsi Jambi. Santri yang berjumlah 669 ini terdiri dari santri kelas I"dadi (Persiapan), Wustha (Madrasah Tsanawiyah), dan „Ulya (Madrasah Aliyah). 


\section{Kendala Pondok Pesantren Salafiah Sa'adatuddaren di Era Modernisasi Pendidikan}

Seiring dengan kuatnya arus modernisasi dan liberalisasi, secara perlahan tapi pasti, model pendidikan ala pondok pesantren salafiah mulai kurang diminati oleh generasi muda sekarang. Hal ini tercermin dari semakin berkurangnya jumlah santri di sebagian besar pondok pesantren di nusantara. Hal ini terjadi karena masyarakat semakin bersifat hedonis dan pragmatis sebagai dampak modernisasi dan globalisasi sehingga biasanya masyarakat cenderung lebih memilih model pendidikan yang lulusannya siap bekerja di dunia industri, perkantoran atau menjadi Pegawai Negeri Sipil. Sementara itu pondok pesantren selama ini memang dikhususkan untuk mencetak ulama guna mengembangkan agama saja sehingga kurang mampu memenuhi tuntutan pasaran kerja masyarakat modern yang berbasiskan skill, ilmu pengetahuan dan penguasaan teknologi modern.

Alasan-alasan yang mendasar juga ikut mengamini para orang tua untuk tidak lagi menitipkan anaknya belajar di pondok pesantren salafiah, proses kegiatan belajar dan mengajar yang dianggap kuno dan tidak lagi relevan dengan kondisi era sekarang yakni modernisasi pendidikan, sarana dan prasana yang tidak memadai, hingga bertaburnya pondok pesantren modern yang lebih menjanjikan para lulusan santri yang memiliki kemampuan dalam kemampuan tekhnologi yang dianggap sesuai dengan permintaan persyaratan lapangan pekerjaan pada saat sekarang ini, lulusanlulusan yang mampu bersaing dalam bursa lapangan pekerjaan yang menuntut seseorang memiliki skill khusus, bersertifikat, dan berijazah.

Wawancara peneliti dengan Wakil Mudir I Pondok Pesantren Salafiah Sa"adatuddaren terkait kendala di era modern ini menuturkan: "majunyo zaman dengan tekhnologi alat-alatnyo yang canggih membuat perubahan galo-galo termasuk pulo dengan pendidikan, pondok pesantren yang terpakso dan dipakso harus ikut merubah caro belajar, fasilitas, supayo dak ketinggalan dan masyarakat tetap percayo bahwo pondok pesantren jugo mampu melahirkan lulusan-lulusan yang dak hanyo ngerti dan faham tentang pelajaran agamo, tapi juga mahir dalam pelajaran umum, tekhnologi, seperti apo yang dituntut oleh lapangan pekerjaan sekarang iko". ${ }^{28}$ (majunya zaman dengan tekhnologinya yang canggih menyebabkan perubahan di setiap aspek, termasuk aspek pendidikan dan khususnya pondok pesantren yang secara terpaksa dan dipaksa ikut memperbarui kegiatan belajar mengajar, sarana dan prasarana, supaya tidak ketinggalan dan tetap dipercaya sebagai lembaga pendidikan yang mampu melahirkan lulusan-lulusan yang tidak hanya mengerti dan faham tentang pelajaran agama, akan tetapi juga mahir dalam pelajaran umum. Seperti sainstek dan tekhnologi sebagaimana yang dituntut oleh lapangan pekerjaan di era modern saat ini).

28 Wakil Mudir I Pondok Pesantren Salafiah Sa'adatuddaren, Ustadz Sulaiman Hasan, 29 Maret 2018, Tahtul Yaman Seberang Kota Jambi, Pena dan Buku Tulis, Kendala Pondok Pesantren Salafiah Sa'adatuddaren di Era Modernisasi Pendidikan. 
Lebih lanjut, Ustadz Sulaiman Hasan menuturkan, kendala Pondok Pesantren Salafiah Sa"adatuddaren di era modernisasi pendidikan erat kaitannya dengan tuntutan kemajuan zaman yang melahirkan sikap instan dan pragmatis bahwa lapangan pekerjaan adalah tujuan utama dari pendidikan itu sendiri. sehingga masyarakat cenderung lebih memilih model pendidikan yang lulusannya siap bekerja di dunia industri, perkantoran atau menjadi Pegawai Negeri Sipil yang saat ini pondok pesantren dianggap tidak mengakomodir hal-hal ini. ${ }^{29}$

\section{Upaya Pondok Pesantren Salafiah Sa'adatuddaren dalam Menjaga Eksistensinya di Era Modernisasi Pendidikan}

Seiring perjalanan waktu, mau tidak mau harus diakui bahwa pada tiga dekade terakhir ini popularitas pondok pesantren salafiah menurun, dan bahkan ada beberapa pondok pesantren salafiah yang ditutup lantaran tidak mampu bertahan dengan perubahan zaman dengan arus modernisasinya. Meskipun ada sebagian pondok pesantren salafiah yang masih survive dan eksis seperti Pondok Pesantren Salafiah Sa'adatuudaren Seberang Kota Jambi yang sedang penulis teliti, namun penurunan popularitas ini tentu turut dirasakan oleh seluruh pondok pesantren salafiah yang masih eksis di era modern saat ini. Perubahan dengan terjadinya evolusi di bidang pendidikan, di mana terjadi pembaharuan termasuk dalam lingkup pendidikan Islam terutama pondok pesantren. Saat ini banyak pondok pesantren yang bergabung dan juga membuka jalur pendidikan formal baik yang berbentuk madrasah maupun sekolah. Dengan mengikuti jalur pendidikan formal para santri umumnya memperoleh ijazah akhir negeri yang menjamin kelangsungan jenjang pendidikan berikutnya atau mempunyai persyaratan untuk mendapatkan suatu pekerjaan.

Wakil Mudir I Ustadz Sulaiman Hasan dalam wawancaranya dengan peneliti memaparkan perubahan yang diupayakan Pondok Pesantren Salafiah Sa"adatuddaren dalam menjaga eksistensinya di era modernisasi pendidikan, ia mengungkapkan: Menghadapi zaman global yang memuat dampak bagi segalonyo termasuk dunio pendidikan, kito perlu mengkaji macammano pondok pesantren menghargoi zaman modern iko. Modernisasi adolah proses transformasi yang idak dapat dihindari, dan kareno itu semuo masyarakat termasuk pondok pesantren harus siap menghadapinyo dan perlu menanggapinyo dengan tebuka dan kritis“. (Menghadapi era globalisasi yang berdampak kepada berbagai perubahan termasuk dunia pendidikan, kita perlu mengkaji bagaimana pondok pesantren mengapresiasikan gejala modernisasi yang berlangsung demikian kuatnya seperti sekarang ini. Modernisasi merupakan proses transformasi yang tak mungkin bisa

${ }^{29}$ Wakil Mudir I Pondok Pesantren Salafiah Sa'adatuddaren, Ustadz Sulaiman Hasan, Wawancara, 29 Maret 2018, Tahtul Yaman Seberang Kota Jambi, Pena dan Buku Tulis, Kendala Pondok Pesantren Salafiah Sa'adatuddaren di Era Modernisasi Pendidikan. 
dihindari, dan karena itu semua kelompok masyarakat termasuk masyarakat pesantren harus siap menghadapinya dan perlu menanggapi gejala-gejalanya secara terbuka dan kritis)". 30

Sejatinya Pondok Pesantren Salafiah Sa"adatuddaren memang masih eksis di tengah perubahan zaman yang ditandai dengan modernisasi dalam setiap aspek kehidupan, termasuk salah satunya modernisasi pendidikan. Namun data dan fakta berbicara bahwa berdasarkan angka, jumlah santri yang saat ini belajar menimba ilmu di Pondok Pesantren Salafiah Sa"adatuddaren yang mengalami penurunan dari tahun ke tahun membuktikan bahwa Pondok Pesantren Salafiah Sa"adatuddaren juga ikut merasakan dampak dari arus modernisasi pendidikan.

Wawancara peneliti dengan Pengurus Bagian Kurikulum Pondok Pesantren Salafiah Sa"adatuddaren, Ustadz Ahmad Mubassir A. Munzir menuturkan "Daren sangat merasokan perubahan tu, perubahan global dunio iko jugo merubah sekolah termasuk pondok pesantren, daren sangat merasokan perubahan dunio pendidikan, kareno orang-orang pingin sekolah negeri yang canggih yang dianggap lebih sesuai dengan keadan lapangan kerjo kini tu, walaupun masih banyak jugo yang nyerahkan anaknyo ke pesantren salafiah macam daren iko" (Sa"adatuddaren sangat merasakan perubahan itu, perubahan dunia global ini juga merubah sekolah termasuk pondok pesantren, Sa"adatuddaren juga merasakan perubahan dunia pendidikan, karena masyarakat lebih memilih sekolah negeri yang canggih yang dianggap lebih sesuai dengan keadaan lapangan kerja saat ini, walaupun masih banyak juga yang menitipkan anaknya ke pesantren salafiah seperti Pondok Pesantren Salafiah Sa"adatuddaren ini). ${ }^{31}$

Berdasarkan pengamatan dan hasil temuan peneliti terhadap upaya yang dilakukan oleh Pondok Pesantren Salafiah S"adatuddaren dalam menghadapi modernisasi pendidikan ini, ada beberapa respon yang cukup positif yang ditunjukan oleh Pondok Pesantren Salafiah Sa"adatuddaren antara lain: ${ }^{32}$ Pertama, melakukan pembenahan dalam ekstrakurikuler dengan pertimbangan menambah wawasan dan mengasah kemampuan santri dalam mengarungi kehidupan di lapangan setelah tamat dari pesantren nanti, Kedua, Sekitar tahun 2001 setelah berdirinya lembaga Pendidikan Diniyah dan Pondok Pesantren yang masih di bawah Kementrian Agama, Pondok Pesantren Salafiah Sa"adatuddaren mulai mendaftarkan diri untuk bergabung kepada kurikulum Kementrian Agama yaitu program pendidikan dasar salafiah dibawah direktorat pendidikan diniyyah dan

30 Wakil Mudir I Pondok Pesantren Salafiah Sa'adatuddaren, Ustadz Sulaiman Hasan, Wawancara 12 April 2018, Tahtul Yaman Seberang Kota Jambi, Pena dan Buku Tulis, Upaya yang dilakukan Pondok Pesantren Salafiah Sa'adatuddaren di Era Modernisasi Pendidikan.

31 Ustadz Pondok Pesantren Salafiah Sa'adatuddaren/ Pengurus Bagian Kurikulum, Ustadz Ahmad Mubassir A. Munzir, Wawancara, 12 April 2018, Tahtul Yaman Seberang Kota Jambi, Pena dan Buku Tulis, Upaya yang dilakukan Pondok Pesantren Salafiah Sa'adatuddaren di Era Modernisasi Pendidikan.

32 Observasi dan temuan peneliti dalam penelitian, Pondok Pesantren Salafiah Sa'adatuddaren, 12 April Tahun 20 
pondok pesantren, serta wajib mengikuti Ujian Nasional Salafiah dan wajib mengajarkan 5 pelajaran umum kepada santri-santrinya yaitu pelajaran Bahasa Indonesia, IPA, IPS, PKN dan Bahasa Inggris, hal ini dipandang sebagai jalan terbaik untuk saat ini dalam menanggapi isu pembelajaran pendidikan Pondok Pesantren Salafiah yang dianggap tidak lagi relevan dengan pendidikan di era modernisasi sekarang ini. Ketiga, menanggapi kekhawatiran masyarakat akan kebutuhan ijazah sebagai bukti seseorang telah menyelesaikan studi pembelajarannya, sebagai syarat untuk melanjutkan tingkat pendidikan ke jenjang berikutnya, Pondok Pesantren Salafiah Sa"adatuddaren mulai mendaftarkan diri untuk bergabung kepada kurikulum kementrian agama yaitu program pendidikan Dasar Salafiahah dibawah Direktorat Pendidikan Diniyah dan Pondok Pesantren. Setelah itu mulailah diperkenalkan kurikulum formalnya, untuk Direktorat Diniyah dan Pondok Pesantren.

\section{Penutup}

Ada beberapa hal penting yang dapat disimpulkan, bahwa Pondok Pesantren Sa"adatuddaren sampai hari ini masih tetap eksis dengan memadukan sitem pendidikan klasik dengan sistem pendidikan modern namun tetap mengedepankan/menstabilkan identitas klasik atau salafiah yaitu kurikulum yang ditetapkan sendiri oleh Pondok sejak awal berdiri, dengan memperdalam kajian kitab kuning yang diajarkan dengan metode klasik seperti metode bandongan, sorogan dan wathonan, menjadikan rujukan dalam pembelajaran dan sebagai ciri khas pondok pesantren salafiah. Dengan visi menciptakan lulusan santri yang berkualitas dikalangan masyarakat menjunjung tinggi nilai-nilai agama ditengah ancaman budaya global. Hal ini dibuktikan dengan minat masyarakat untuk menyekolahkan anaknya di Pondok Pesantren Salafiah Sa"adatuddaren masih tetap terjaga walaupun tidak dapat dipungkiri apabila dibandingkan dengan waktu masa kejayaan pondok pesantren ini dalam jumlah angka memang mengalami penurunan. Akan tetapi santri yang belajar di Pondok Pesantren Salafiah Sa"adatuddaren saat ini masih tergolong banyak dan para santri ini berasal dari berbagai kabupaten-kabupaten yang ada di daerah di provinsi Jambi bahkan dari luar provinsi seperti Riau, Palembang, hingga Sumatera Utara dan Sumatera Barat sebagai bukti kongkrit bahwa Pondok Pesantren Salafiah Sa"adatuddaren masih eksis dan dikenal hingga luar provinsi. 


\section{Bibliografi}

Abdul Majid dan Jusuf Mudzakkir, Ilmu Pendidikan Islam, (Jakarta: Kencana Prenada Media, 2010)

Abidin Zaenal, Analisis Eksistensial, (Jakarta: PT. Raja Grafindo Persada, 2007),

Abudin Nata, Sejarah Pendidikan Islam pada Periode Klasik dan Modern, (Jakarta: Raja Grapindo Persada, 2010),

Abdul Hamid, Pemikiran Modern dalam Islam, (Bandung: Pustaka Setia, 2010),

Amin Haedari, dkk, Masa Depan Pesantren; dalam Tantangan Modernitas dan Tantangan Komplesitas Global, (Jakarta: IRD Press, 2008),

Anonim, Pola Pengembangan Pondok pesantren (Jakarta: Ditpekapontren, 2008)

Anonim, Pendidikan Islam dan Pendidikan Nasional (Paradigma Baru), (Jakarta: Ditpekapontren, 2007)

Azyumardi Azra, Jaringan Ulama Timur Tengah dan Kepulauan Nusantara Abad XVII dan XVIII, (Bandung: Mizan, 2014).

Arief Subhan, Lembaga Pendidikan Islam Indonesia Abad Ke-20: Pergumulan antara Modernisasi dan Identitas, (Jakarta: Kencana, 2012)

Enung K Rukiati \& Fenti Hikmawati, Sejarah Pendidikan Islam di Indonesia, (Bandung: Pustaka Setia, 2013),

Halim dkk, Manajemen Pesantren (Yogyakarta: LKiS Printing Cemerlang, 2008) hal. 78.

Hasbullah, Kapita Selekta Pendidikan Islam, (Jakarta: PT. Raja Grafindo Persada, 2008)

Jasa Ungguh Muliawan, Pendidikan Islam Integratif; Upaya Mengintegrasikan Kembali Dikotomi Ilmu dan Pendidikan Islam, (Yogyakarta: Pustaka Pelajar, 2005),

Lexy J. Moleong, Metodologi Penelitian Kualitatif, (Bandung: Remaja Rosda Karya, 2010)

Mukhtar, Bimbingan Skripsi, Tesis, dan Artikel Ilmiah, (Jakarta: Gaung Persada Press, 2007)

Misiak, H \& Sexton, V, Psikologi Fenomenologi, Eksistensial, dan Humanistik, (Bandung: Refika Aditama, 2009),

Muhmidayeli, (et.al.), Membangun Paradigma Pendidikan Islam, (Pekanbaru: Program Pascasarjana UIN Suska Riau, 2007),

Mukhtar, Metode Praktis Penelitian Deskriptif Kualitatif, Jakarta: Referensia-GP. Press Group, 2013),

Nurcholish Madjid, Bilik-Bilik Pesantren (Jakarta: Dian Rakyat, 2010),

Qomar, Mujamil, Manajemen Pendidikan Islam; Strategi Baru Pengelolaan Lembaga Pendidikan Islam, (Jakarta: Erlangga, 2010),

Samsul Nizar, Sejarah Pendidikan Islam: Menelusuri Jejak Pendidikan Era Rasulullah sampai Indonesia, (Jakarta: Kencana, 2008)

Tim Prima Pena, Kamus Lengkap Bahasa Indonesia, (tk.: Gitamedia Press, tt.), Suwito, Sejarah Sosial Pendidikan Islam, (Jakarta: Kencana, 2008). 